\title{
Extracellular proteinases from Micrococcus GF : II. Isolation and characterization
}

\author{
GD García de Fernando *, PF Fox
}

\author{
Department of Food Chemistry, University College, Cork, Ireland
}

(Received 19 September 1990; accepted 30 January 1991)

\begin{abstract}
Summary - Micrococcus sp GF, a microorganism isolated from a farmhouse blue cheese, produced 2 extracellular proteinases, I and II, which were purified $\approx 4000$ times to homogeneity with a yield of $\approx 10 \%$ by ultrafiltration, dialysis, freeze-drying and chromatography on DEAE-cellulose and Sephadex G-150. The optimum temperature for activity was around $45^{\circ} \mathrm{C}$ for both enzymes. Proteinase I exhibited a $\mathrm{pH}$ optimum at 8.5 while proteinase II had a very broad optimum at $\mathrm{pH} 9.0$ to 11.0. Both proteinases were activated by low concentrations of $\mathrm{NaCl}$. They were considered to be metalloproteinases since they were inhibited by EDTA. Proteinase I was irreversibly inactivated by EDTA while the activity of apo-proteinase II was restored by treatment with $\mathrm{Ca}^{2+}, \mathrm{Ba}^{2+}, \mathrm{Mg}^{2+}, \mathrm{Sr}^{2+}$ or $\mathrm{Zn}^{2+}$. Both proteinases were inhibited by several heavy metals. Proteinase II was stimulated by some ions, especially $\mathrm{Mg}^{2+}$, while proteinase I was not. Molecular weights were estimated by SDSPAGE to be around 23.5 and $42.5 \mathrm{kDa}$ for proteinases I and II, respectively. Proteinase I hydrolyzed $\beta$-casein preferentially to $\alpha_{\mathrm{s}}$-casein, while proteinase II hydrolyzed both caseins at approximately the same rate.
\end{abstract}

\section{extracellular proteinase / Micrococcus}

Résumé - Protéinase extracellulaire de Micrococcus GF: II. Isolement et caractérisation. Micrococcus sp GF, un microorganisme isolé à partir d'un fromage bleu fermier, produit deux protéinases extracellulaires, protéinases l et II. Elles ont été purifiées $\approx 4000$ fois, avec un rendement de $\approx$ $10 \%$, jusqu'à homogénéité, par ultrafiltration, dialyse, lyophilisation et chromatographie sur DEAEcellulose et Sephadex G-150.

La température optimale d'activité pour les deux enzymes est d'environ $45^{\circ} \mathrm{C}$. Le pH optimum d'activité de l'enzyme l est de 8,5 tandis que celui de l'enzyme II s'étend de 9 à 11. Les 2 protéinases sont activées par de faibles concentrations en $\mathrm{NaCl}$. Elles sont considérées comme des métalloprotéinases car elles sont inhibées par l'EDTA. L'EDTA a inactivé irréversiblement la protéinase I tandis que l'activité de l'apo-protéinase II a été restaurée par des traitements au $\mathrm{Ca}^{2+}, \mathrm{Ba}^{2+}, \mathrm{Mg}^{2+}, \mathrm{Sr}^{2+}$ ou $\mathrm{Zn}^{2+}$. Plusieurs métaux lourds inhibent les deux protéinases. Certains ions, $\mathrm{Mg}^{2+}$ en particulier, stimulent l'activité de la protéinase II mais pas celle de la protéinase I.

Les poids moléculaires, estimés pour les 2 protéinases l et II par électrophorèse SDS-PAGE, étaient respectivement, voisins de 23,5 et de $42,5 \mathrm{kDa}$. La protéinase I hydrolyse préférentiellement la caséine $\beta$ à la caséine $\alpha_{s}$; tandis que la protéinase II hydrolyse les 2 caséines avec approximativement la même intensité.

\section{protéinase extracellulaire / Micrococcus}

\footnotetext{
* Correspondence and reprints, present address : Departamento de Higiene y Tecnología de los Alimentos, Facultad de Veterinaria, 28040 Madrid, Spain
} 


\section{INTRODUCTION}

Micrococci have been reported as one of the components of cheese microflora (eg Irvine and Beach, 1962; Obradovic, 1978; Ordóñez et al, 1978; Bhowmik and Marth, 1990) and may contribute to cheese flavour through their lipolytic and/or proteolytic activities (Marth, 1963; Bhowmik and Marth, 1990) or through a symbiotic activation of lactobacilli (Nath and Ledford, 1971). Several attempts have been made to use micrococci to improve and enhance Cheddar flavour and to accelerate ripening (Deane, 1951; Robertson and Perry, 1961).

Intracellular proteolytic and peptidase activities from micrococci have been reported; eg Baribo and Foster (1952) reported that the intracellular proteinases and peptidases of $M$ freudenreichii contributed to the proteolytic activity in cheese. Nath and Ledford (1972) and Bhowmik and Marth (1988) detected intracellular proteolytic activity in all strains studied.

It is known that some Micrococcus spp are endowed with extracellular proteolytic activity, eg Husain and McDonald (1958) reported the partial purification of an extracellular proteinase from $M$ freudenreichii. Desmazeaud and Hermier (1968, 1971) isolated and characterized an extracellular proteinase produced by $M$ caseolyticus. Nath and Ledford (1972) detected extracellular proteolytic activity in 3 of 18 Micrococcus strain isolated from Cheddar cheese. Prasad et al (1986) isolated a metalloproteinase from Micrococcus MCC315.

The objective of the present study was to isolate and characterize the proteinases from Micrococcus GF, isolated from the surface of a farmhouse blue cheese. The influence of several factors in the growth of, and proteinase production by, this or- ganism was reported by García de Fernando and Fox (1991).

\section{MATERIALS AND METHODS}

\section{Culture conditions}

Stock cultures of Micrococcus (Kocur, 1986) GF were maintained frozen in $2 \%$ phytone peptone broth (BBL Microbiology Systems, Cockeysville, $M D$, USA) until required. When required, 2-1 flasks, each containing $700 \mathrm{ml}$ of $2 \%$ phytone peptone (BBL), were inoculated with Micrococcus GF and incubated at $30^{\circ} \mathrm{C}$ on a rotary shaker operating at $100 \mathrm{rpm}$ for $40 \mathrm{~h}$.

\section{Purification}

Cell-free supernatant (CFS) was prepared by centrifuging the grown culture in a Sorvall RC $5 \mathrm{~B}$ centrifuge at $4{ }^{\circ} \mathrm{C}$ at $15000 \mathrm{~g}$ for $10 \mathrm{~min}$. CFS was ultrafiltered to $\approx 1 / 10$ volume reduction in a Millipore Minetan (Massachusetts, USA) ultrafiltration system, fitted with polysulphone membranes with a nominal molecular weight cut-off of $10 \mathrm{kDa}$. The retentate was dialyzed against 10 । of $2 \mathrm{mM} \mathrm{CaCl}_{2}-20 \mathrm{mmol}^{-1}$ Tris(hydroxymethyl)aminomethane (Tris)maleate buffer, pH 8.5 , at $4^{\circ} \mathrm{C}$ overnight. The dialyzed CFS was chromatographed at $4{ }^{\circ} \mathrm{C}$ on a $70 \times 2.5 \mathrm{~cm}$ column of DEAE-cellulose (Whatman $D E 23$ ), previously equilibrated in $2 \mathrm{mmol}^{-1}$ $\mathrm{CaCl}_{2}-20$ mmol. $^{-1}$ Tris-maleate, buffer, $\mathrm{pH} 8.5$. Adsorbed proteins were eluted with a linear $\mathrm{NaCl}$ gradient, $0-0.75$ mmol. $^{-1}$. Fractions (10 $\mathrm{ml}$ ) were collected in a LKB Redirac 2112 fraction collector. The fractions were analyzed for absorbance at $280 \mathrm{~nm}$, proteolytic activity and $\mathrm{NaCl}$ (Fox, 1963).

Some of the proteolytic activity did not adsorb on DEAE-cellulose under the experimental conditions while the remainder adsorbed and was eluted in the $\mathrm{NaCl}$ gradient; the active fractions for each enzyme were pooled. The pooled fractions were dialyzed against 2 mmol..$^{-1}$ $\mathrm{CaCl}_{2}-20$ mmol. $^{-1}$ Tris-maleate buffer, $\mathrm{pH} 8.5$, to remove $\mathrm{NaCl}$. Both enzyme preparations were freeze-dried and chromatographed at $4{ }^{\circ} \mathrm{C}$ 
on a $76 \times 2.5 \mathrm{~cm}$ column of Sephadex G-150 that had been previously equilibrated with 2 mmol. $.^{-1} \mathrm{CaCl}_{2}-20$ mmol. I $^{-1}$ Tris-maleate buffer, $\mathrm{pH}$ 8.5. Fractions $(10 \mathrm{ml})$ were collected and analyzed for absorbance at $280 \mathrm{~nm}$ and proteolytic activity. Proteolytically active fractions were pooled, freeze-dried and rechromatographed on Sephadex G-150.

\section{Protein measurement}

Protein was calculated from absorbances at 280 $n m$, using $A_{280}^{1 \%}=10$.

\section{Proteinase assay}

Proteolytic activity was measured using azocasein as substrate (Sigma Chemical Co Ltd, Dorset, UK). Samples ( $1 \mathrm{ml}$ ) of enzyme were added to $1 \mathrm{ml}$ of $0.8 \%$ azocasein solution in 0.2 mol. $^{-1}$ Tris- $\mathrm{HCl}$ buffer, $\mathrm{pH} 8.5$ or 9.1 (for unadsorbed and adsorbed proteinases, respectively). The mixture was incubated at $45^{\circ} \mathrm{C}$ for $2 \mathrm{~h}$. The reaction was stopped by adding $1 \mathrm{ml}$ of $6 \%$ trichloroacetic acid, the mixture filtered through Whatman No 42 paper and the absorbance of the filtrates measured at $440 \mathrm{~nm}$. One proteolytic activity unit represented a $\Delta \mathrm{A}_{440}$ of 1 at $45^{\circ} \mathrm{C}$ in $2 \mathrm{~h}$ per $\mathrm{ml}$ of sample.

\section{Sodium dodecyl sulphate polyacryla- mide gel electrophoresis (SDS-PAGE)}

SDS-PAGE was performed as described by Greaser et al (1983) using Coomassie blue R250 as dye. Electrophoretograms were run with standards (Sigma) of known molecular weight (lysozyme (14.3 kDa), $\quad \beta$-lactoglobulin (18.4 $\mathrm{kDa})$, trypsinogen $(24 \mathrm{kDa})$, pepsin $(34.7 \mathrm{kDa})$, ovalbumin (45 kDa) and bovine serum albumin $(66 \mathrm{kDa}))$.

\section{Optimum temperature}

Proteolytic activity was assayed at temperatures ranging from $19-74{ }^{\circ} \mathrm{C}$; before addition of enzyme, the substrate was tempered at the appropriate temperature.

\section{Optimum pH}

Azocasein was dissolved in universal buffer (Dawson et al, 1969), which contained citric acid $(6.008 \mathrm{~g}), \mathrm{KH}_{2} \mathrm{PO}_{4}(3.893 \mathrm{~g}), \mathrm{H}_{3} \mathrm{BO}_{3}(1.769 \mathrm{~g})$, barbitone $(5.266 \mathrm{~g})$, and the $\mathrm{pH}$ adjusted to values in the range $4.0-13.0$ with $0.2 \mathrm{M} \mathrm{NaOH}$. Proteolytic activity was assayed at $45^{\circ} \mathrm{C}$ for $2 \mathrm{~h}$.

\section{Heat stability}

Enzyme preparations, dissolved in $2 \mathrm{mM} \mathrm{CaCl}_{2}-$ $20 \mathrm{mM}$ Tris-maleate, $\mathrm{pH} 8.5$, were heated at temperatures in the range $60.0-69.5^{\circ} \mathrm{C}$. Aliquots were taken at intervals up to $2 \mathrm{~h}$ and transferred to tubes in a water/ice bath. Proteolytic activity was assayed at $45^{\circ} \mathrm{C}$ for $2 \mathrm{~h}$.

\section{Effect of chemical reagents and metal ions}

$\mathrm{K}^{+}, \mathrm{Cs}^{+}, \mathrm{Zn}^{2+}, \mathrm{Mg}^{2+}, \mathrm{Fe}^{3+}, \mathrm{Fe}^{2+}, \mathrm{Ba}^{2+}, \mathrm{Cd}^{2+}$, $\mathrm{Co}^{2+}, \mathrm{Cu}^{2+}, \mathrm{Mn}^{2+}, \mathrm{Ca}^{2+}, \mathrm{Hg}^{2+}$ (as chlorides or sulphates), EDTA, 1,10-phenanthroline and $\mathrm{N}$ ethylmaleimide were added at different concentrations to aliquots of the enzyme preparations and maintained at room temperature for $1 \mathrm{~h}$; remaining proteolytic activity was then assayed. The effect of $\mathrm{NaCl}$ at concentrations ranging from 0.0 to $3.0 \mathrm{M}$ on proteolytic activity was assayed.

\section{Reactivation of apo-enzyme}

The enzymes were inactivated by making the solution to $2 \mathrm{mM}$ EDTA at $20^{\circ} \mathrm{C}$ for $1 \mathrm{~h}$. The solutions were then dialyzed against distilled water overnight. Different concentrations of $\mathrm{Ba}^{2+}$, $\mathrm{Ca}^{2+}, \mathrm{Mg}^{2+}, \mathrm{Sr}^{2+}, \mathrm{Co}^{2+}$ and $\mathrm{Zn}^{2+}$ were added to the dialyzed preparation, maintained at room temperature for $1 \mathrm{~h}$ and then assayed for proteoIytic activity.

\section{Casein fractionation}

Sodium caseinate $(1 \mathrm{~g})$ was dissolved in distilled water and applied to a $69 \times 2.5 \mathrm{~cm}$ column of 
DEAE-cellulose previously equilibrated at $4{ }^{\circ} \mathrm{C}$ with 0.02 mol. $^{-1}$ phosphate buffer, $\mathrm{pH} 6.5$. Adsorbed caseins were eluted at $4{ }^{\circ} \mathrm{C}$ with a linear gradient of $\mathrm{NaCl}\left(0.0\right.$ to $\left.0.5 \mathrm{~mol}^{-1} \mathrm{I}^{-1}\right)$. Absorbance at $280 \mathrm{~nm}$ was measured and $\mathrm{NaCl}$ determined by titration with $\mathrm{AgNO}_{3}$ (Fox, 1963). Protein-rich fractions showed 4 peaks which were pooled, dialyzed against distilled water for $36 \mathrm{~h}$ and lyophilized. These were shown by urea-PAGE (Andrews, 1983) to contain mainly $\gamma, \beta, \kappa$ and $\alpha_{s}$-caseins.

\section{Caseinolytic activity of Micrococcus GF}

Sodium caseinate or freeze-dried $\alpha_{s}$ and $\beta$ caseins were dissolved at $0.5 \%(\mathrm{w} / \mathrm{v})$ in $0.2 \mathrm{M}$ Tris- $\mathrm{HCl}$ buffer, $\mathrm{pH} 8.5$, and enzyme preparations were added. The mixtures were incubated at $45^{\circ} \mathrm{C}$. Aliquots were taken at different times and added to equal volumes of sample buffer for electrophoresis (Andrews, 1983). Electrophoresis was performed according to Andrews
(1983). Gels were stained by the method of Blakesley and Boezi (1977).

\section{Milk clotting}

Samples $(10 \mathrm{ml})$ of a $10 \%$ solution of reconstituted milk powder in $3 \mathrm{mM} \mathrm{CaCl}$ were incubated with 0.35 unit of proteinase I or 0.14 unit of proteinase $\mathrm{II}$ at $37^{\circ} \mathrm{C}$ for $2 \mathrm{~h}$.

\section{RESULTS}

\section{Purification}

A typical elution profile of concentrated CFS from DEAE-cellulose is shown in figure 1. Two peaks with proteolytic activity were detected; the more active peak (I)

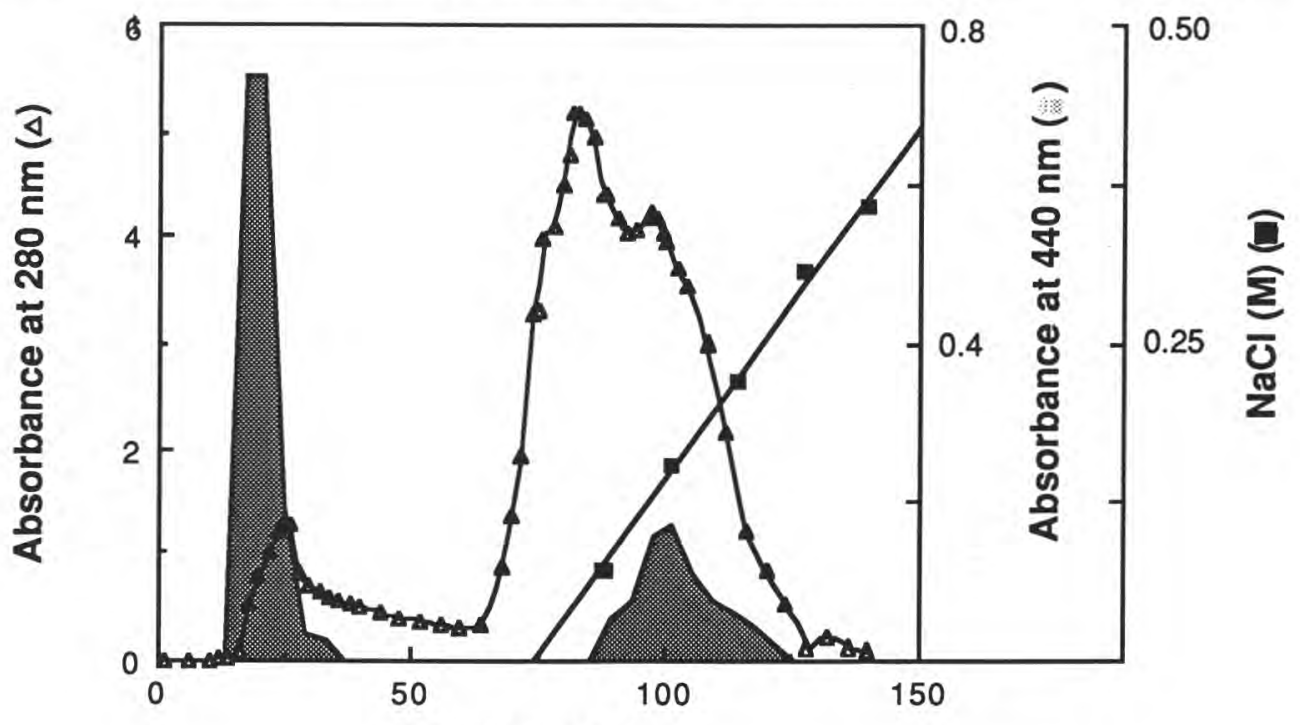

\section{Fraction number}

Fig 1. Elution profile of dialyzed, ultrafiltered, cell-free supernatant of Micrococcus GF from DEAEcellulose equilibrated with $2 \mathrm{mM} \mathrm{CaCl} \mathrm{Cl}_{2}-20 \mathrm{mM}$ Tris-maleate buffer, $\mathrm{pH} 8.5$ using a linear $\mathrm{NaCl}$ gradient, $0-0.5 \mathrm{M}$, at $4{ }^{\circ} \mathrm{C}$. Column size : $70 \times 2.5 \mathrm{~cm}$. Flow rate : $0.35 \mathrm{ml} / \mathrm{min}$. Fraction size : $10 \mathrm{ml}$.

Chromatographie sur DEAE-cellulose équilibrée en tampon $2 \mathrm{mM} \mathrm{CaCl} \mathrm{Cl}_{2}-20 \mathrm{mM}$ Tris-maléate, $\mathrm{pH} 8.5$ du surnageant de Micrococcus GF. Volume de la colonne : $70 \times 2,5 \mathrm{~cm}$. Débit : 0,35 ml/min. Volume des fractions : $10 \mathrm{ml}$. 
was not adsorbed on DEAE-cellulose, while the other (II) was adsorbed and eluted by $\approx 0.24 \mathrm{M} \mathrm{NaCl}$. The proteolytically active fractions were pooled, dialyzed overnight against $10 \mathrm{I}$ of $2 \mathrm{mM} \mathrm{CaCl}-20$ $\mathrm{mM}$ Tris-maleate buffer, $\mathrm{pH} 8.5$ and freeze-dried.

The dried preparations were chromatographed on a Sephadex G-150 column (76 $\times 2.5 \mathrm{~cm}$ ) at $4^{\circ} \mathrm{C}$. Proteolytic fractions were pooled, freeze-dried and rechromatographed on Sephadex G-150 (76 × 2.5 $\mathrm{cm})$. The chromatograms of proteinase preparations I and II are shown in figure 2. A reduction of the absorbance at $280 \mathrm{~nm}$ was observed on rechromatography, with very little loss of activity. Table I shows the progress of purification and yields of the enzymes through the main stages. The final purification observed for both proteinases was $>4000$-fold with an activity yield of $\approx 10 \%$.

Homogeneity of the purified enzymes was assessed by SDS-PAGE using $\approx 20$ $\mu \mathrm{g}$ of protein per slot and staining with Coomassie brilliant blue R-250. Only one stained band was evident in each of the purified enzyme preparations. The molecular weights were estimated to be $\approx 23500$ and $42500 \mathrm{Da}$ for proteinases I and II, respectively.

\section{Optimum temperature}

Proteinases I and II from Micrococcus GF were optimally active at $45^{\circ} \mathrm{C}$. Below $20^{\circ} \mathrm{C}$, activity was $<20 \%$ of maximum and above $50^{\circ} \mathrm{C}$ it decreased markedly.

\section{Optimum pH}

Proteinase I showed maximum activity at $\mathrm{pH} 8.5$ and activity decreased markedly below $\mathrm{pH} 8.0$, being totally lost at $\mathrm{pH} 4.0$. However, activity decreased only slightly

Table I. Purification of the extracellular proteinases of Micrococcus GF.

Purification de l'activité protéolytique extracellulaire de Micrococcus GF.

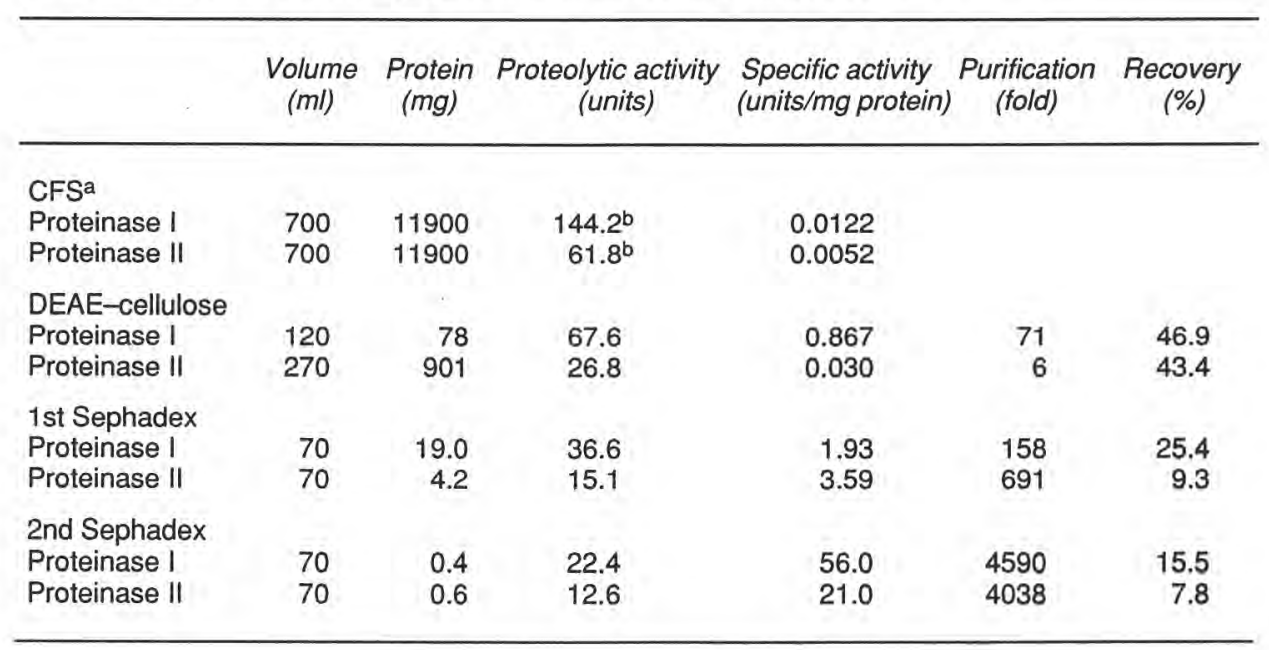

\footnotetext{
${ }^{a}$ Cell-free supernatant from centrifugation. ${ }^{b}$ Values estimated from experimental data.
} 

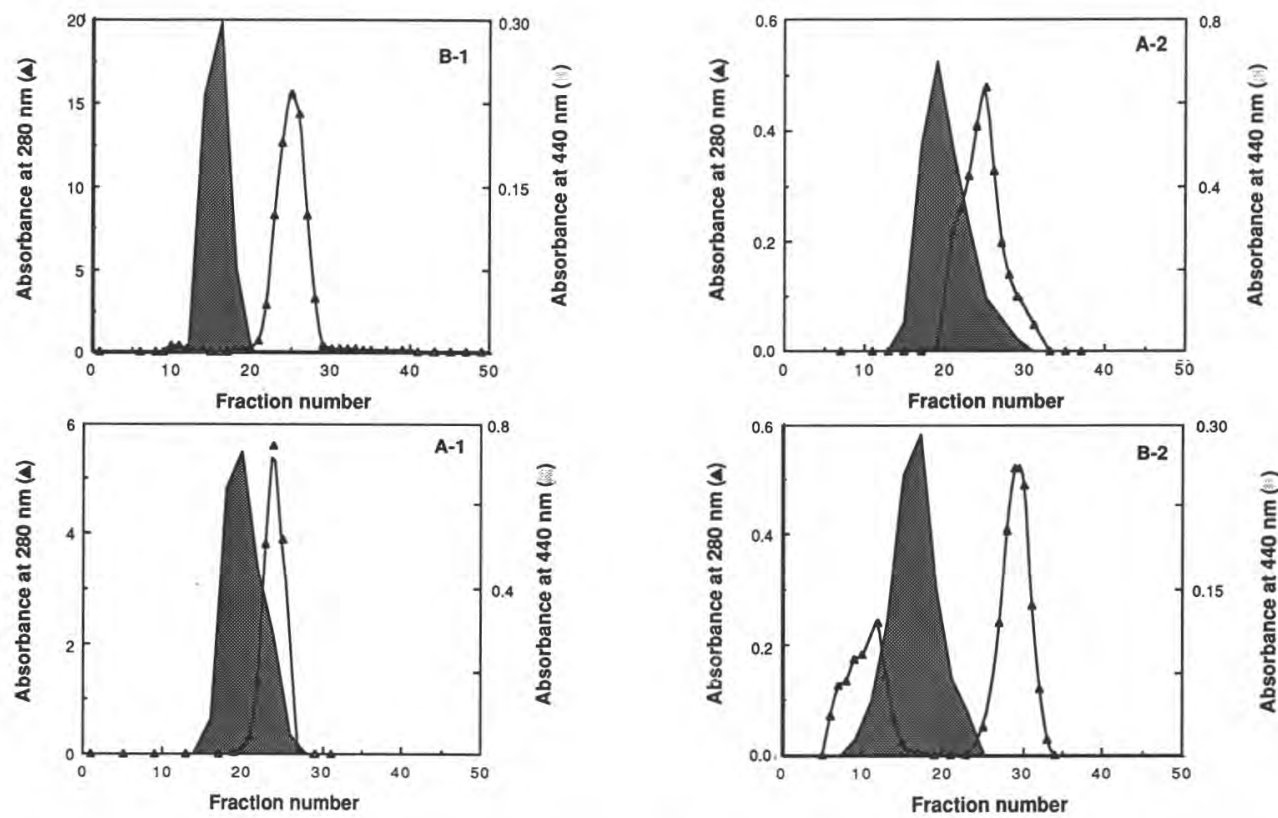

Fig 2. Elution profiles of peaks I (A) and II (B) from DEAE-cellulose chromatographed $(A)$ and rechromatographed (2) on Sephadex G-150. Column size: $76 \times 2.5 \mathrm{~cm}$. Eluent: $2 \mathrm{mM} \mathrm{CaCl}-20 \mathrm{mM}$ Trismaleate buffer, $\mathrm{pH} 8.5$. Flow rate: $\approx 0.3 \mathrm{ml} / \mathrm{min}$. Fraction size: $10 \mathrm{ml}$. Temperature: $4^{\circ} \mathrm{C}$.

Chromatographie (1) et rechromatographie (2) sur Sephadex G-150 des pics I (A) et II (B) qui ont été séparés sur DEAE-cellulose. Volume de la colonne : $76 \times 2,5 \mathrm{~cm}$. Débit : $\approx 0,3 \mathrm{ml} / \mathrm{min}$. Volume des fractions : $10 \mathrm{ml}$.

from $\mathrm{pH} 9.0$ to 12.0 and sharply above this value. Proteinase II was inactive at $\mathrm{pH} 4.5$, but activity increased markedly between $\mathrm{pH} 4.5$ and 6.0 and was maximal in the range 9.0-11.0. Activity markedly decreased above the last value.

\section{Effect of $\mathrm{NaCl}$}

The activity of proteinases I and II was increased by low $\mathrm{NaCl}$ concentrations; maximum activity was detected at $0.20 \mathrm{M} \mathrm{NaCl}$ for proteinase $\mathrm{I}$ and at $0.35 \mathrm{M}$ for proteinase II. The activity of proteinase I decreased markedly with increasing $\mathrm{NaCl}$ concentration in the range $0.2-1.0 \mathrm{M}$ and slightly thereafter, while the activity of proteinase II decreased linearly with increasing $\mathrm{NaCl}$ concentration > $0.35 \mathrm{M}$; neither enzyme was active in $4 \mathrm{M} \mathrm{NaCl}$.

\section{Effect of metal ions}

After exposing the enzymes to different concentrations of several ions at room temperature for $1 \mathrm{~h}$, the mixtures were assayed for proteolytic activity. The effect of the ions on proteinase activity is shown in figure 3. Enzyme I was strongly inhibited by $\mathrm{Fe}^{2+}, \mathrm{Zn}^{2+}, \mathrm{Cd}^{2+}, \mathrm{Co}^{2+}$ and $\mathrm{Hg}^{2+}$, mildly 
by $\mathrm{Fe}^{3+}, \mathrm{Cu}^{2+}$ and $\mathrm{Mn}^{2+}$, while $\mathrm{Mg}^{2+}, \mathrm{Ca}^{2+}$, $\mathrm{Ba}^{2+}, \mathrm{Cs}^{2+}$ and $\mathrm{K}^{+}$did not affect activity. Enzyme II was strongly inhibited by $\mathrm{Fe}^{2+}$, $\mathrm{Fe}^{3+}, \mathrm{Co}^{2+}$ and $\mathrm{Hg}^{2+}$, mildly by $\mathrm{Cu}^{2+}, \mathrm{Cd}^{2+}$, $\mathrm{Mn}^{2+}$ and $\mathrm{Zn}^{2+}, \mathrm{Cs}^{+}$and $\mathrm{K}^{+}$had no effect while $\mathrm{Ba}^{2+}, \mathrm{Ca}^{2+}$, and especially $\mathrm{Mg}^{2+}$, stimulated proteolytic activity.
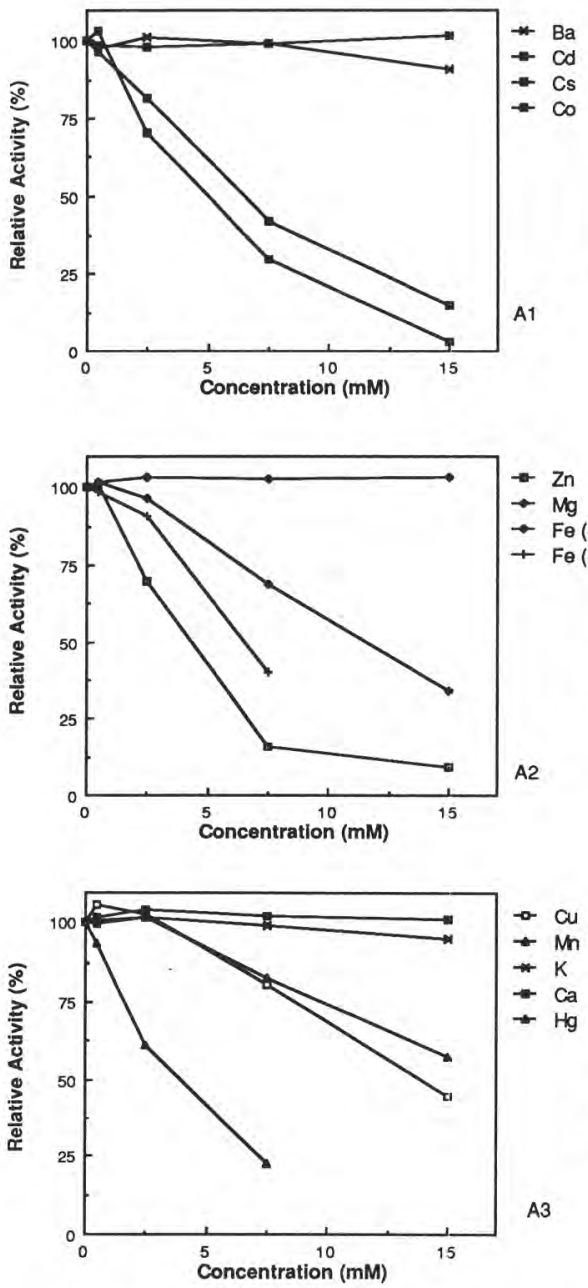

\section{Effect of N-ethylmaleimide (NEM)}

Proteinase I was slightly inhibited above 1 $\mathrm{mM} \mathrm{NEM}$ but retained $\approx 75 \%$ of its original activity in the presence of $20 \mathrm{mM}$ NEM. NEM did not affect the activity of proteinase II in the range studied.
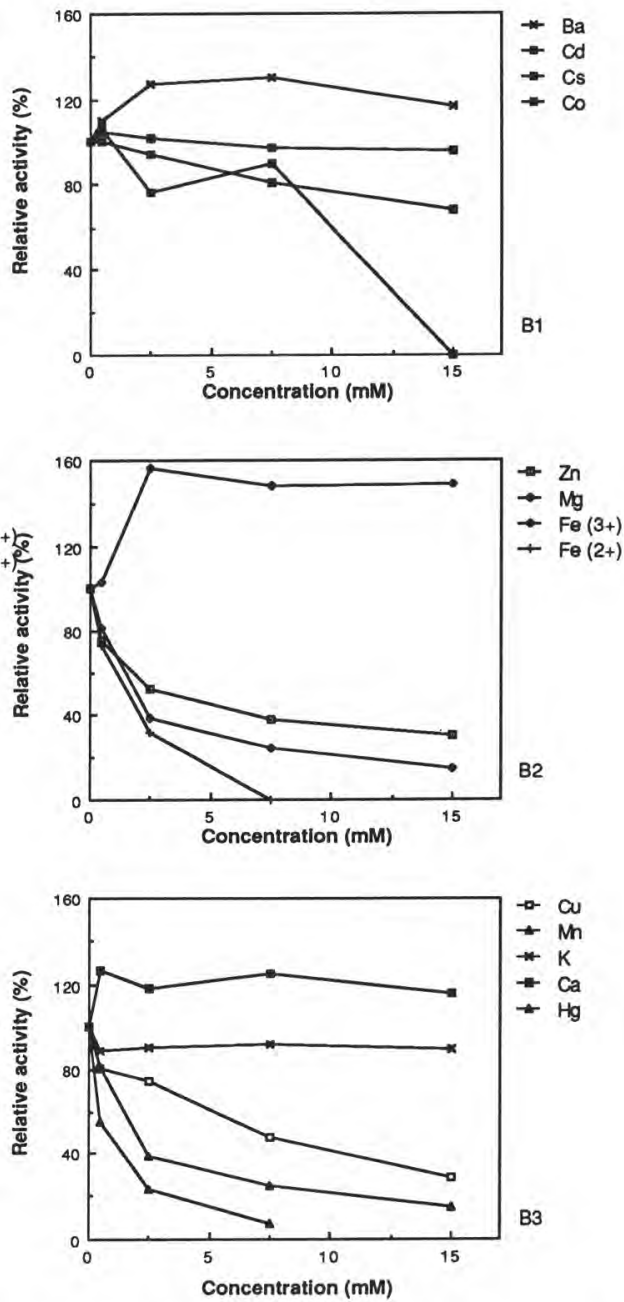

Fig 3. Effect of metals on the activity of the extracellular proteinases I (A) and II (B) of Micrococcus $\mathrm{GF}$ at pH 8.5 (proteinase I) or 9.1 (proteinase II) and $45^{\circ} \mathrm{C}$.

Effet des ions métaux sur l'activité des protéinases extracellulaires I (A) et II (B) de Micrococcus GF à pH 8,5 (protéinase I) ou pH 9,1 (protéinase II) et à $45^{\circ} \mathrm{C}$. 


\section{Effect of metal chelators}

1,10 -Phenanthroline, in the range $0-25$ $\mathrm{mM}$, did not affect the activity of the extracellular proteinases of Micrococcus GF. At $0.05 \mathrm{mM}$, EDTA did not affect proteinase activities. Above this concentration, the activity of both proteinases decreased markedly and they were completely inhibited at 1 mM EDTA.

\section{Reactivation by metal ions}

Samples of proteinases I and II were inactivated by treatment with EDTA $(2 \mathrm{mM})$ and then dialyzed against distilled water. Proteinase I was not reactivated by any of the ions tested, while proteinase II was reactivated (fig 4) by $\mathrm{Ca}^{2+}, \mathrm{Ba}^{2+}, \mathrm{Sr}^{2+}, \mathrm{Mg}^{2+}$ or $\mathrm{Zn}^{2+}$ but not by $\mathrm{Co}^{2+}$. $\mathrm{Mg}^{2+}$ and $\mathrm{Zn}^{2+}$ reactivated the enzyme to $\approx 150 \%$ of the orig-

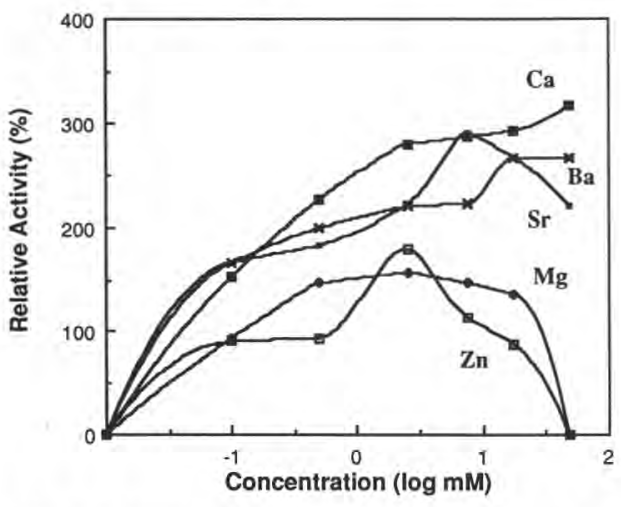

Fig 4. Reactivation of EDTA (2 mM)-treated extracellular proteinase II of Micrococcus GF by metal ions at $\mathrm{pH} 9.1$ and $45^{\circ} \mathrm{C}$. Values are relative to the activity (100) of an enzyme sample that had not been treated with EDTA.

Réactivation de la protéinase II de Micrococcus GF traitée avec l'EDTA (2 mM) par les ions métaux à $\mathrm{pH} 9,1$ et à $45^{\circ} \mathrm{C}$. Les valeurs sont reportées à l'activité (100) d'une enzyme qui n'a pas été traitée avec l'EDTA. inal activity, although above this concentration the extent of the reactivation decreased. $\mathrm{Sr}^{2+}$ gave maximum reactivation at $10 \mathrm{mM}$ and its effectivness decreased slightly thereafter. $\mathrm{Ba}^{2+}$, and especially $\mathrm{Ca}^{2+}$, increased the activity of the enzyme up to $50 \mathrm{mM}$ (the highest concentration tested) when the activity of the reactivated enzyme was $300 \%$ that of the control (without EDTA treatment).

\section{Thermostability}

The thermostability of the proteinases was studied in $2 \mathrm{mM} \mathrm{CaCl}_{2}-20 \mathrm{mM}$ Trismaleate buffer, $\mathrm{pH}$ 8.5. The thermal inactivation plots are shown in figure 5 . Dvalues were numerically calculated from the experimental data and are shown in table II. Likewise, Z-values were calculated from a graph (fig 6) which represents logarithms of D-values against temperature. Both enzymes were thermolabile; Z-values were $7.58^{\circ} \mathrm{C}$ and $5.35^{\circ} \mathrm{C}$ for proteinases I and II, respectively.

\section{Caseinolytic properties}

On $0.5 \%$ sodium caseinate at $\mathrm{pH} 8.5$, proteinase I hydrolyzed $\beta$-casein more rapidly than $\alpha_{\mathrm{s}}$-casein but both caseins were completely hydrolyzed to a variety of peptides in $\approx 2 \mathrm{~h}$ (fig 7). Proteinase II hydrolyzed both $\alpha_{s^{-}}$and $\beta$-caseins at approximately equal rates to a wide range of products (fig $8 \mathrm{~A}, \mathrm{~B})$.

Solutions of $\alpha_{s}$ and $\beta$-caseins became turbid during incubation with the enzymes. The rate of increase and the intensity of the turbidity was greater when proteinase I was used. The turbidity disappeared after long incubation. 

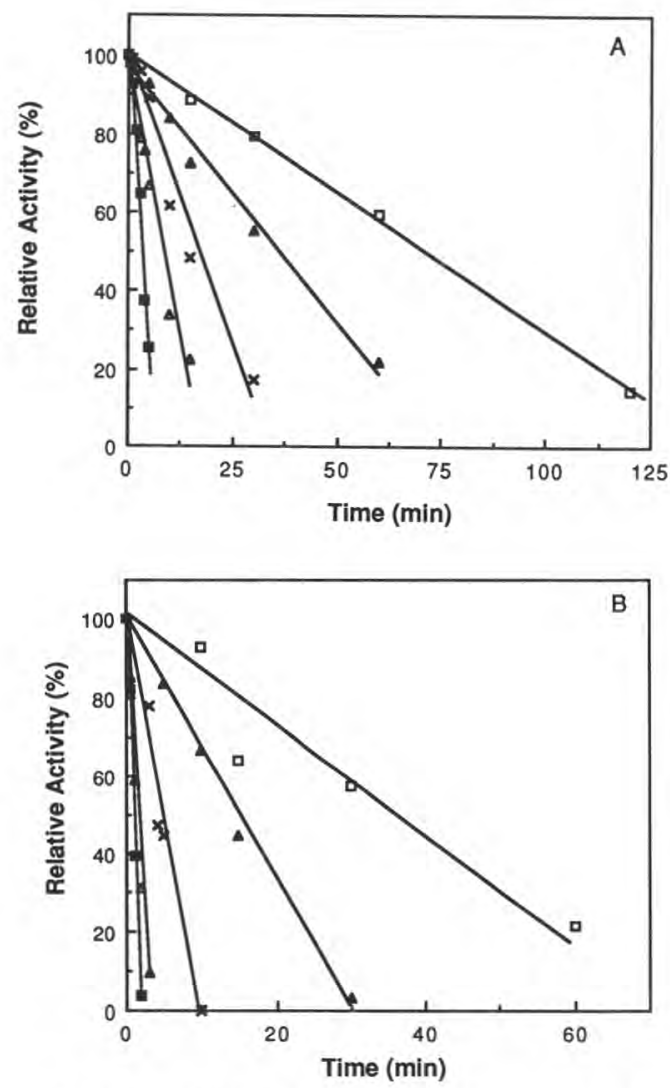

Fig 5. Residual activity of heat-treated extracellular proteinases I (A) and II (B) of Micrococcus $\mathrm{GF}$ in $2 \mathrm{mM} \mathrm{CaCl}_{2}-20 \mathrm{mM}$ Tris, $\mathrm{pH}$ 8.5. Proteolytic activity was measured at $\mathrm{pH} 8.5$ (proteinase l) or 9.1 (proteinase II) and $45^{\circ} \mathrm{C}$. $\square 60.0^{\circ} \mathrm{C}$; $62.5^{\circ} \mathrm{C} ; \mathrm{X} 65.0^{\circ} \mathrm{C} ; \Delta 67.5^{\circ} \mathrm{C}$; $69.5^{\circ} \mathrm{C}$.

Activité résiduelle des protéinases extracellulaires de Micrococcus GF qui ont été soumises à des traitements thermiques. L'activité protéolytique était mesurée à $\mathrm{pH} 8,5$ (protéinase l) ou $\mathrm{pH} \mathrm{9,1} \mathrm{(protéinase} \mathrm{II)} \mathrm{et} \mathrm{à} 45^{\circ} \mathrm{C} . \square 60.0^{\circ} \mathrm{C}$; $\triangle$ $62.5^{\circ} \mathrm{C} ; \times 65.0^{\circ} \mathrm{C} ; \Delta 67.5^{\circ} \mathrm{C} ; 69.5^{\circ} \mathrm{C}$.

\section{Milk clotting}

Neither proteinases clotted milk under the experimental conditions, ie $\mathrm{pH} 6.6$ at $37^{\circ} \mathrm{C}$ for $2 \mathrm{~h}$, even at the high enzyme levels used.

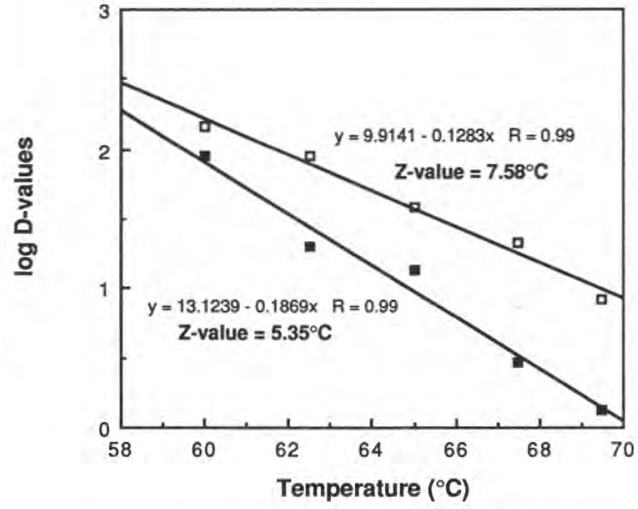

Fig 6. Z-values for the heat inactivation of extracellular proteinase I (D) and II (四) of Micrococcus GF in $2 \mathrm{mM} \mathrm{CaCl}_{2}-20 \mathrm{mM}$ Tris, $\mathrm{pH} 8.5$. Valeurs $Z$ pour l'inactivation par la chaleur des protéinases I (口) et II (घ) de Micrococcus GF.

\section{DISCUSSION}

Micrococcus GF produced 2 extracellular proteinases which were purified to homogeneity $\approx 4000$ fold with a total yield of $\approx$ $10 \%$ by ultrafiltration, dialysis, freezedrying and chromatography on DEAEcellulose and Sephadex G-150. Prasad et al (1986) purified the extracellular proteinase from Micrococcus MCC-315 $\approx 80$ fold with a yield $>50 \%$. Desmazeaud and Hermier (1968) reported a final purification for the proteinase of $M$ caseolyticus of $\approx 40$ fold with a recovery of $7 \%$. The purification method described here was similar to that used by Desmazeaud and Hermier (1968) and by Prasad et al (1986). The main difference was the first step: precipitation by $\left(\mathrm{NH}_{4}\right)_{2} \mathrm{SO}_{4}$ was used in the other studies while ultrafiltration was used in the present study. Precipitation with $\left(\mathrm{NH}_{4}\right)_{2} \mathrm{SO}_{4}$ frequently causes loss of activity, while ultrafiltration caused no loss of activity. 


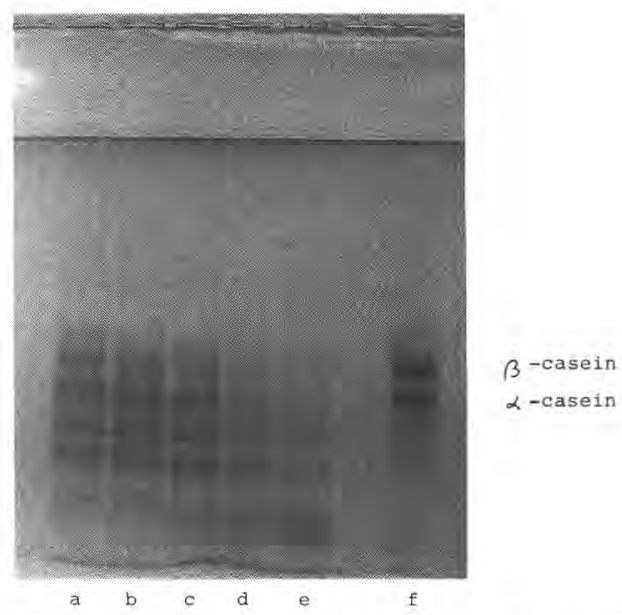

Fig 7. Urea-PAGE of $1 \mathrm{ml}(5 \mathrm{mg} / \mathrm{ml})$ of casein incubated with 0.07 units of proteinase I from Micrococcus GF at $45^{\circ} \mathrm{C}$ and pH 8.5 for 5 (a), 15 (b), 30 (c), 60 (d), 120 (e) and 0 (f) min.

PAGE en présence d'urée de $1 \mathrm{ml}(5 \mathrm{mg} / \mathrm{ml})$ de caséine qui a été incubée avec 0,07 unité de protéinase I de Micrococcus GF pendant 5 (a), 15 (b), 30 (c), 60 (d), 120 (e) et $O(f)$ min à $45^{\circ} \mathrm{C}$ et à $\mathrm{pH} 8,5$.

The optimum temperature for the activity of both extracellular proteinases of $\mathrm{Mi}$ crococcus GF was $45^{\circ} \mathrm{C}$. The extracellular proteinases from $M$ freudenreichii (Husain and McDonald, 1958) and M caseolyticus
(Desmazeaud and Hermier, 1968) were optimally active at $50{ }^{\circ} \mathrm{C}$. Prasad et al (1986) reported optimum temperatures of 37 and $60^{\circ} \mathrm{C}$, depending on the substrate used, for the extracellular proteinase of $\mathrm{Mi}$ crococcus MCC-315. All these proteinases, including those from Micrococcus GF, retained less than $20 \%$ of maximum activity at $20^{\circ} \mathrm{C}$. In most cases, activity decreased markedly at temperatures $>50^{\circ} \mathrm{C}$.

The $\mathrm{pH}$ optimum reported for the extracellular proteinases of Micrococcus spp varied widely: 5.7 at 35 or $45^{\circ} \mathrm{C}$ and 6.7 at $20^{\circ} \mathrm{C}$ for the extracellular proteinase of $M$ freudenreichii (Husain and McDonald, 1958), 7.6 for the proteinase from $M$ caseolyticus (Desmazeaud and Hermier, 1968), 10.6 for Micrococcus MCC-315 (Prasad et al, 1986) and 8.5 for proteinase I and 9.0 to 12.0 for proteinase II of Micrococcus GF. The extracellular proteinase from $M$ freudenreichii can be considered as an acid proteinase, that from $M$ caseolyticus as a neutral proteinase and those from Micrococcus MCC-315 and Micrococcus GF as alkaline proteinases.

Proteinases I and II of Micrococcus GF were optimally active in 0.20 and $0.35 \mathrm{M}$ $\mathrm{NaCl}$, respectively. McDonald (1961) reported that $\mathrm{NaCl}$ protected the extracellular proteinase of $M$ freudenreichii against inactivation. However, Prasad et al (1986) re-

Table II. D-values ( $\mathrm{min}$ ) for the thermal inactivation of the extracellular proteinases of Micrococcus GF in $2 \mathrm{mM} \mathrm{CaCl}_{2}-20 \mathrm{mM}$ Tris-maleate, $\mathrm{pH} 8.5$.

Valeur $D$ (min) pour l'inactivation thermique des protéinases extracellulaires de Micrococcus GF dans $2 \mathrm{mM} \mathrm{CaCl}_{2}-20 \mathrm{mM}$ Tris-maléate, $\mathrm{pH} 8,5$.

\begin{tabular}{lrrrrr}
\hline & \multicolumn{5}{c}{ Temperature $\left({ }^{\circ} \mathrm{C}\right)$} \\
\cline { 2 - 6 } & 60.0 & 62.5 & $\begin{array}{c}65.0 \\
\text { D-values }(\min )\end{array}$ & 67.5 & 69.5 \\
\hline Proteinase I & 144.93 & 90.09 & 37.88 & 21.50 & 8.44 \\
Proteinase II & 89.28 & 19.84 & 13.78 & 2.95 & 1.32 \\
\hline
\end{tabular}



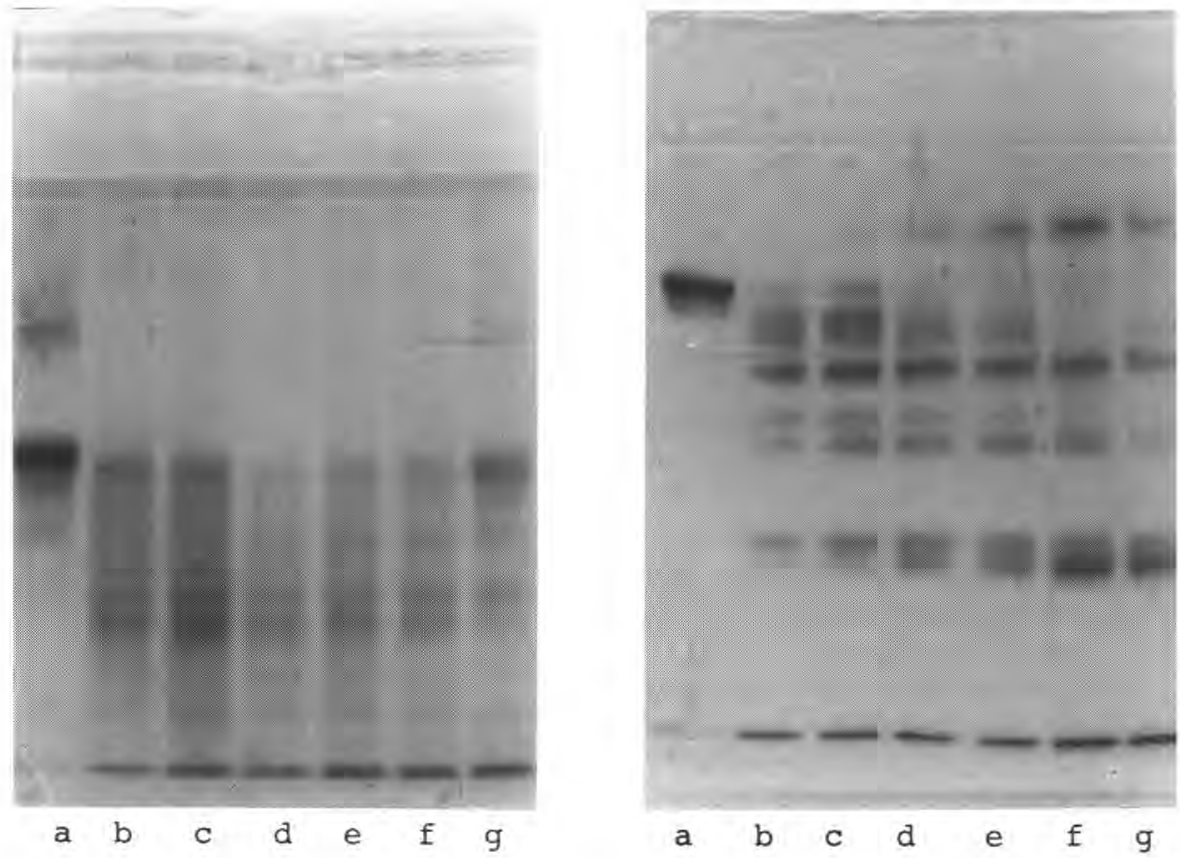

Fig 8. Urea-PAGE of $1 \mathrm{ml}(5 \mathrm{mg} / \mathrm{ml})$ of $\alpha_{\mathrm{s}^{-}}(\mathrm{A})$ and $\beta$-casein $(B)$ incubated with 0.02 units of proteinase II from Micrococcus GF for 0 (a), 10 (b), 30 (c), 60 (d), 90 (e), 120 (f) and 180 (g) min at $45^{\circ} \mathrm{C}$ and $\mathrm{pH} 9.1$.

PAGE en présence d'urée de $1 \mathrm{ml}(5 \mathrm{mg} / \mathrm{ml})$ de $\alpha s-(A)$ et $\beta$-(B) caséines qui ont été incubées avec 0,02 unité de protéinase II de Micrococcus GF pendant $O$ (a), 10 (b), 30 (c), 60 (d), 90 (e), 120 (f) et $180 \mathrm{~g} g) \min$ à $45^{\circ} \mathrm{C}$ et à $\mathrm{pH} 9,1$.

ported that the activity of the extracellular proteinase of Micrococcus MCC-315 was reduced by $4-10 \%$ in the presence of 1.3 mmol. $\left.\right|^{-1} \mathrm{NaCl}$ compared to the control without added salt.

Metal ions inhibit many enzymes but it is difficult to compare the results obtained by different authors since different salts at different concentrations or under different conditions have been used. $\mathrm{Fe}^{2+}, \mathrm{Co}^{2+}$ and $\mathrm{Hg}^{2+}$ inhibited the proteinases of $\mathrm{Mi}$ crococcus GF. $\mathrm{Hg}^{2+}$ is a common enzyme inhibitor; $\mathrm{Co}^{2+}$ and $\mathrm{Fe}^{2+}$ also completely or partially inhibited the proteinase from $M$ caseolyticus (Desmazeaud and Hermier, 1968), but stimulated the extracellular proteinase of Micrococcus MCC-315 (Prasad et al, 1986). $\mathrm{Zn}^{2+}$ or $\mathrm{Cd}^{2+}$, which partially inhibited the proteinases of Micrococcus GF, also partially inhibited the proteinase of $M$ caseolyticus (Desmazeaud and Hermier, 1968). $\mathrm{Mn}^{2+}$ stimulated the extracellular proteinase of Micrococcus MCC-315 (Prasad et al, 1986) but inhibited the proteinase of $M$ caseolyticus (Desmazeaud and Hermier, 1968) and inhibited the proteinases of Micrococcus GF. $\mathrm{Cu}^{2+}$ has been reported to inhibit all the proteinases discussed here. $\mathrm{Ca}^{2+}, \mathrm{Mg}^{2+}, \mathrm{Sr}^{2+}$ or $\mathrm{K}^{+}$did not affect the activity of the extracellular proteinase of $M$ caseolyticus (Desmazeaud and Hermier, 1968) while $\mathrm{Ca}^{2+}$ or $\mathrm{Sr}^{2+}$ stimulated the activity of the proteinase of Micrococcus MCC-315 (Prasad et 
al, 1986). Proteinase I of Micrococcus GF was not affected by $\mathrm{Ca}^{2+}, \mathrm{Ba}^{2+}, \mathrm{Mg}^{2+}$ or $\mathrm{K}^{+}$, but proteinase II was stimulated by $\mathrm{Ba}^{2+}, \mathrm{Ca}^{2+}$ and especially by $\mathrm{Mg}^{2+}$.

The failure of NEM to inhibit the proteinases of Micrococcus GF suggested that are not thiol-proteinases. The inhibitory effect of EDTA indicates that they are metalloenzymes, but neither molecule appears to contain $\mathrm{Zn}^{2+}$ since neither was inhibited by 1,10-phenanthroline. Many microbial proteinases are $\mathrm{Zn}$-metalloenzymes (see McKellar, 1989), however, although some micrococcal proteinases are metalloenzymes, there is no evidence that the extracellular proteinases of Micrococcus spp contain $\mathrm{Zn}^{2+}$. The extracellular proteinase from $M$ sodonensis (now reclassified as $M$ luteus (Baird-Parker, 1974)) is probably not a metalloproteinase (Mills and Campbell, 1974).

Proteinase II, after inhibition with EDTA, could be reactivated by $\mathrm{Zn}^{2+}, \mathrm{Mg}^{2+}, \mathrm{Sr}^{2+}$ and especially by $\mathrm{Ba}^{2+}$ or $\mathrm{Ca}^{2+}$, while proteinase I was irreversibly inactivated by EDTA. The proteinase of Micrococcus MCC-315 was also irreversibly inactivated by EDTA (Prasad et al, 1986). The proteinase from $M$ caseolyticus could be partially reactivated by $\mathrm{Sr}^{2+}$ and $\mathrm{Ca}^{2+}$ (Desmazeaud and Hermier, 1968).

Both proteinases from Micrococcus GF extensively degraded $\alpha_{s}$ - and $\beta$-caseins. Proteinase I degraded $\beta$-casein preferentially to $\alpha_{\mathrm{s}}$-casein (fig 7) but, proteinase II degraded these caseins at about the same rate (fig 8). Electrophoretic studies on the degradation of $\alpha_{s^{-}}$and $\beta$-caseins by cell free extracellular extracts from cultures of $M$ caseolyticus ATCC $13458, M$ freudenreichii ATCC 407, M luteus 10240 and Micrococcus sp ATCC 8459 demonstrated that they preferentially hydrolysed $\beta$-casein but also hydrolysed $\alpha_{s 1}$-casein (Nath and Ledford, 1972; Bhowmik and Marth, 1988).
The use of $\beta$-caseinolytic micrococci in cheesemaking to accelerate ripening was suggested by Bohwmik and Marth (1988). If the hydrolysis of $\beta$-casein does improve cheese flavour or accelerate ripening, the use of Micrococcus GF as a starter, or the addition of a partially purified proteinase preparation to cheese curd may be interesting. $\beta$-casein is a source of hydrophobic peptides, which may be bitter (Visser et al, 1982). Therefore, if enzymes which preferentially degrade $\beta$-casein are used in cheesemaking careful regulation of the dose is essential.

\section{REFERENCES}

Andrews AT (1983) Proteinases in normal bovine milk and their action on caseins. J Dairy Res 50, 45-55

Baird-Parker AC (1974) Micrococci. In: Bergey's Manual of Determinative Bacteriology (Buchanan RE, Gibbons NE, eds) Williams \& Wilkins Co, Baltimore, USA, 8th edn, 478483

Baribo LE, Foster EM (1952) The intracellular proteinases of certain organisms from cheese and their relationship to the proteinases in cheese. J Dairy Sci 35, 149-160

Bhowmik T, Marth EH (1988) Protease and peptidase activity of Micrococcus species. $J$ Dairy Sci 71, 2358-2365

Bhowmik T, Marth EH (1990) Role of Micrococcus and Pediococcus species in cheese ripening: a review. J Dairy Sci 73, 859-866

Blakesley RW, Boezi JA (1977) A new staining technique for proteins in polyacrylamide gels using Coomassie brilliant blue G250. Anal Biochem 82, 580-582

Dawson RMC, Elliot DC, Elliot WH, Jones KM (1969) Data for Biochemical Research. Clarendon Press, Oxford, UK, 2nd edn, 465

Deane DD (1951) Preliminary studies of the effect of acido-proteolytic organisms and temperatures of curing on the ripening of Cheddar cheese made from pasteurized milk. $J$ Dairy Sci 34, 7-13 
Desmazeaud M, Hermier J (1968) Isolement, purification et propriétés d'une protéase exocellulaire de Micrococcus caseolyticus. Ann Biol Anim Biochim Biophys 8, 565-577

Desmazeaud M, Hermier J (1971) Spécificité de la protéase neutre de Micrococcus caseolyticus. Eur J Biochem 19, 51-55

Fox PF (1963) Potentiometric determination of salt in cheese. J Dairy Sci 46, 744-745

Garcia de Fernando GD, Fox PF (1991) Extracellular proteinases from Micrococcus GF I. Factors affecting growth and production. Lait 3, 371-382

Greaser ML, Yates LD, Krzwycki K, Roelke DL (1983) Electrophoretic methods for the separation and identification of muscle proteins. Rec Meat Conf Proc 36, 87-90

Husain I, McDonald IJ (1958) Characteristics of an extracellular proteinase from Micrococcus freudenreichii. Can J Microbiol 4, 237-242

Irvine OR, Beach ME (1962) Methods for enumerating non-lactic organisms in fresh Cheddar cheese. J Dairy Sci 45, 648

Kocur M (1986) Genus I. Micrococcus. In: Bergey's Manual of Systematic Bacteriology (Sneath PHA, Mair NS, Sharpe ME, Holt JG, eds), Williams \& Wilkins Co, Baltimore, USA, vol 2, 9th edn, 1004-1008

Marth EH (1963) Microbiological and chemical aspects of Cheddar cheese ripening. $J$ Dairy Sci $46,869-890$

McDonald IJ (1961) Proteinase production in relation to growth of a Micrococcus species. Can J Microbiol 7, 111-117
McKellar RC (1989) Enzymes of Psychrotrophs in Raw Foods (McKellar RC, ed) CRC Press, FL, USA

Mills C, Campbell JN (1974) Production and control of extracellular enzymes in Micrococcus sodonensis. Can J Microbiol 20, 81-90

Nath KR, Ledford RA (1971) Stimulation of the rate of acid production by lactobacilli in media containing a capsular substance from $\mathrm{mi}-$ crococci. J Dairy Sci 54, 1784-1789

Nath KR, Ledford RA (1972) Caseinolytic activity of micrococci isolated from Cheddar cheese. J Dairy Sci 55, 1424-1427

Obradovic D (1978) Application of mixed starters in the production of Trappist cheese. Proc 20th Int Dairy Congr E572

Ordoñez JA, Barneto R, Ramos M (1978) Studies on Manchego cheese ripened in olive oil. Milchwissenschaft 33, 609-613

Prasad R, Malik RK, Mathur DK (1986) Purification and characterization of extracellular caseinolytic enzyme of Micrococcus sp MCC315 isolated from Cheddar cheese. J Dairy Sci 69, 633-642

Robertson PS, Perry KDS (1961) Enhancement of flavor of Cheddar cheese by adding a strain of Micrococcus to the milk. J Dairy Res $28,245-253$

Visser S, Slangen KJ, Hup G, Exterkate FA, Stadhouders J (1982) The bitter flavour defect in cheese - some chemical and microbiological aspects. Voedingsmiddelentechnologie 15, 28; abstr, Food Sci Technol Abstr (1984) $16(9), 174$ 